\title{
Reckoning with colonial injustice: International law as culprit and as remedy?
}

\author{
Carsten Stahn* \\ Leiden Law School, Steenschuur 25, 2311 ES Leiden, The Netherlands; Queen's University Belfast, University Rd, Belfast BT7 \\ 1NN, United Kingdom \\ E-mail: c.stahn@law.leidenuniv.nl
}

To fall under the spell of an object, to be touched by it, moved emotionally by a piece of art in a museum, brought to tears of joy, to admire its forms of ingenuity, to like the artworks' colors, to take a photo of it, to let oneself be transformed by it: all these experiences-which are also forms of access to knowledge-cannot simply be reserved to the inheritors of an asymmetrical history.

Felwin Sarr and Bénédicte Savoy, 2018

\section{Introduction}

Colonial injustice is not a distant wrong that passes away with time. ${ }^{1}$ It is an everyday reality that reproduces itself. Its ongoing effects are vividly illustrated by controversies of the return of cultural colonial objects, ${ }^{2}$ the rise of the 'Black Lives Matter' movement, contemporary debates about the concept of 'race' or the discourse over slavery-related monuments. In the course of the twentieth century, 'overt structures of colonialism were slowly dismantled', but some of 'its underlying principles were implicitly reinforced'. ${ }^{3}$ Hannah Arendt has highlighted the structural synergies between colonialism and twentieth century totalitarianism in the 1950s. ${ }^{4}$ The (after)life of colonialism remains present in our relations to spaces, objects, persons or history. ${ }^{5}$

Few theories of justice have addressed the ongoing problems posed by the historical reality of colonialism. Cases relating to colonial crimes have fallen outside contemporary understandings of atrocity crime or law as an institution itself. Judge Pal, the only representative of the colonized

${ }^{*}$ I wish to thank Eric de Brabandere and Ingo Venzke for their comments.

${ }^{1}$ See S. Löytömäki, 'The Law and Collective Memory of Colonialism: France and the Case of "Belated” Transitional Justice', (2013) 7 International Journal of Transitional Justice 205, at 222. See also J. Balint et al., Keeping Hold of Justice: Encounters between Law and Colonialism (2020).

${ }^{2}$ See A. Tasdelen, The Return of Cultural Artefacts: Hard and Soft Law Approaches (2016); J. Van Beurden, Treasures in Trusted Hands: Negotiating the Future of Colonial Objects (2017); A. Vrdoljak, International Law, Museums and the Return of Cultural Objects (2006); E. Campfens, ‘The Bangwa Queen: Artifact or Heritage?', (2019) 26 International Journal of Cultural Property 75.

${ }^{3}$ Vrdoljak, ibid., at 193.

${ }^{4} \mathrm{H}$. Arendt, The Origins of Totalitarianism (1951), 123-5.

${ }^{5}$ See A. Césaire, Discourse on Colonialism (2000); F. Fanon, Black Skin, White Masks (2008); D. Moses, Empire, Colony, Genocide (2008); G. Coulthard, Red Skin, White Masks: Rejecting the Colonial Politics of Recognition (2014).

(C) The Author(s), 2020. Published by Cambridge University Press. This is an Open Access article, distributed under the terms of the Creative Commons Attribution-NonCommercial-NoDerivatives licence (http://creativecommons.org/licenses/by-nc-nd/4.0/), which permits noncommercial re-use, distribution, and reproduction in any medium, provided the original work is unaltered and is properly cited. The written permission of Cambridge University Press must be obtained for commercial re-use or in order to create a derivative work. 
world at Tokyo, openly criticized the failure of the tribunal to engage with 'political domination'6 and the 'plague of imperialism' in its construction of international law in the aftermath of the Second World War. He noted:

I do not see how we can shut our eyes to the period beyond an arbitrarily fixed limit. The approach suggested ... would afford an easy solution of all our bewilderment. But I am not sure if it would lead us to anything which in the name of humanity we can call wholesome and salutary. ${ }^{7}$

The non-Aligned movement has fought for over 50 years to end colonialism, ${ }^{8}$ but broader moves to seek redress for slavery ${ }^{9}$ or colonial violations have been marginalized during decolonization and the Cold War. ${ }^{10}$ Issues of justice or reparation were often sidelined in the path towards independence and decolonization. The international legal system failed to engage with its own past. This status quo affects the very identity of international society, including its proclaimed universality, commitment to equality or narratives of progress. Failing to 'deal properly with historical injustice' is 'an injustice in itself'. ${ }^{11}$

Over the past two decades, the need to engage with this chapter of the past has gained broader public consciousness. Cities, universities and museums have started to engage more critically with their colonial heritage (e.g., benefits from slave trade, naming of streets and public spaces). ${ }^{12}$ In some cases, former colonial powers have expressed remorse or apologies for different types of historical injustice. ${ }^{13}$ The Durban Conference stressed the link between historical wrong and ongoing inequality and discrimination and advocated a development-based vision of compensatory justice. ${ }^{14}$ Specific episodes of colonial and post-colonial violence have been subject to investigation or litigation in domestic courts, such as British atrocity in the Mau Mau uprising, ${ }^{15}$ Dutch crimes in the decolonization of the East Indies (Rawagade, South Salawesi), ${ }^{16}$ the assassination of

\footnotetext{
${ }^{6} \mathrm{Pal}$ criticized the selective focus on the 'menace of totalitarianism'. See IMTFE, 'Dissentient Judgment of Justice Pal' (1999), at 117.

${ }^{7}$ Ibid.

${ }^{8}$ See J. von Bernstorff and P. Dann, The Battle for International Law: South-North Perspectives on the Decolonization Era (2019); L. Eslava, M. Fakhri and V. Nesiah, Bandung, Global History, and International Law: Critical Pasts and Pending Futures (2017). See also the Charter on Economic Rights and Duties of States, Art. 16, GA Res. 29/3281 (XXIX), UN Doc. A/RES/29/3281 (1974).

${ }^{9}$ On the origins see A. L. Araujo, Reparations for Slavery and the Slave Trade: A Transnational and Comparative History (2017). See also J. Torpey, Making Whole What Has Been Smashed (2006); J. Torpey (ed.), Politics and the Past: On Repairing Historical Injustices (2003); F. Brennan and J. Packer (eds.), Colonialism, Slavery, Reparations and Trade Remedying the 'Past'? (2012).

${ }^{10}$ E. Barkan, The Guilt of Nations: Restitution and Negotiating Historical Injustices (2001).

${ }^{11}$ A. De Baets, 'Historical Imprescriptibility', (2011) 59/60 Storia della Storiographia 128, at 149.

${ }^{12}$ For instance, the University of Glasgow recognized that it received 'significant financial support' from slavery in the eighteenth and nineteenth centuries and made a plan for reparatory justice. Postcolonial associations have been formed in various German cities, such as Berlin postcolonial, Hamburg postcolonial. For museum practices, see inter alia NMVW, 'Return of Cultural Objects: Principles and Process' (2019).

${ }^{13}$ See R. Brooks, 'The Age of Apology', in R. Brooks (ed.), When Sorry Isn't Enough: The Controversy over Apologies and Reparations for Human Injustice (1999), at 3-11; T. Bentley, Empires of Remorse (2016).

${ }^{14}$ World Conference Against Racism, Racial Discrimination, Xenophobia and Related Intolerance, Declaration and Programme of Action (2002), Art. 158. See E. Tourme-Jouannet, 'Reparations for Historical Wrongs: The Lessons of Durban', in E. Tourme-Jouannet (ed.), What is a Fair International Society? (2013), at 187-201.

${ }^{15} \mathrm{C}$. Elkins, Imperial Reckoning: The Untold Story of Britain's Gulag in Kenya (2005).

${ }^{16}$ See E. de Volder and A. de Brouwer, The Impact of Litigation in relation to Systematic and Large-Scale Atrocities committed by the Dutch Military Forces in the 'Dutch East Indies' between 1945-1949 (2019); L. van den Herik, 'Addressing "Colonial Crimes" through Reparation? Adjudicating Dutch Atrocities committed in Indonesia', (2012) 10 JICJ 693; N. Immler and S. Scagliola, 'Seeking justice for the mass execution in Rawagede', (2020) 24 Rethinking History 1.
} 
Lumumba and the kidnapping of mixed-race children (Métis), ${ }^{17}$ or the claims of Herero and Nama against Germany's massacre in Namibia. ${ }^{18}$ Contemporary initiatives, such as the 2013 CARICOM Plan for Reparatory Justice, ${ }^{19}$ the 2018 Sarr and Savoy report on restitution of cultural heritage, ${ }^{20}$ EU resolutions on looted art, and changing museum practices ${ }^{21}$ illustrate that the ongoing structural and relational dimensions of colonial injustice require novel attention. ${ }^{22}$

On 17 June 2020, UN High Commissioner of Human Rights, Michelle Bachelet, openly criticized 'the failure to acknowledge and confront the legacy of the slave trade and colonialism' in the Human Rights Council Urgent Debate on current racially inspired human rights violations. ${ }^{23}$ She combined this with a plea 'to make amends for centuries of violence and discrimination, including through formal apologies, truth-telling processes, and reparations in various forms' ${ }^{24}$ However, state discourses on apologies, reparatory justice or engagement with colonial history remain overshadowed by colonial amnesia, different readings of the past or reluctance to remedy wrong. ${ }^{25}$

This editorial seeks to address the schizophrenic role of international law towards colonial injustice. It builds on the rich tradition of this journal in relation to the colonial foundations of international law and post-colonial approaches, including in recent years (e.g., Hébié, ${ }^{26}$ Sellars, ${ }^{27}$ Strecker, ${ }^{28}$ Tzouvala, ${ }^{29}$ Nuzzo $^{30}$ and Giladii ${ }^{31}$. It argues that international law needs a fresh relational understanding in order to engage critically with its own foundations and decolonize its own structures. It first addresses the dual role of international law as culprit and remedy and false dichotomies in discourses on reparatory justice. It then introduces relational theories, which offer new frames for reparatory justice. It concludes with some thoughts on how to re-think international law from a relational perspective, in order to enable more responsible engagement with the colonial past.

\footnotetext{
${ }^{17}$ In the parliamentary inquiry, Belgium acknowledged moral, but no legal responsibility. A criminal investigation in relation to Lumumba's death was opened in 2011. See H. Hintjens and S. Cruz, 'Continuities of violence in the Congo: Legacies of Hammarskjöld and Lumumba', in C. Stahn and H. Melber (eds.), Peace Diplomacy, Global Justice and International Agency (2014), at 216-37. In April 2019, the Belgian Prime Minister issued an apology in relation to the treatment of the Métis children under Belgian colonial rule.

${ }^{18}$ J. Sarkin, Colonial Genocide and Reparations Claims in the 21st Century (2008); H. Melber, 'Germany and Namibia: Negotiating Genocide', (2020) Journal of Genocide Research, available at doi.org/10.1080/14623528.2020.1750823.

${ }^{19}$ CARICOM Reparations Commission, '10-Point Reparation Plan' (2014).

${ }^{20}$ F. Sarr and B. Savoy, 'The Restitution of African Cultural Heritage: Toward a New Relational Ethics', November 2018, available at restitutionreport2018.com/sarr_savoy_en.pdf.

${ }^{21}$ EU Parliament, Cross-border restitution claims of works of art and cultural goods looted in armed conflicts and wars, Res. 2017/2023 (2019).

${ }^{22}$ See also M. Moran, 'The problem of the past: How historic wrongs became legal problems', (2019) 69 University of Toronto Law Journal 421.

${ }^{23}$ Statement by Michelle Bachelet, UN High Commissioner for Human Rights, $43^{\text {rd }}$ session of the Human Rights Council Urgent Debate on current racially inspired human rights violations, systemic racism, police brutality against people of African descent and violence against peaceful protests, 17 June 2020.

${ }^{24}$ Ibid.

${ }^{25}$ On redress see D. Butt, Rectifying International Injustice: Principles of Compensation and Restitution Between Nations (2009).

${ }^{26}$ M. Hébié, 'Was There Something Missing in the Decolonization Process in Africa?: The Territorial Dimension', (2015) 28 LJIL 529.

${ }^{27} \mathrm{~K}$. Sellars, 'Meanings of Treason in a Colonial Context: Indian Challenges to the Charges of "Waging War against the King" and "Crimes against Peace", (2017) 30 LJIL 825.

${ }^{28}$ A. Strecker, 'Indigenous Land Rights and Caribbean Reparations Discourse', (2017) 30 LJIL 629.

${ }^{29}$ N. Tzouvala, 'A False Promise? Regulating Land-grabbing and the Post-colonial State', (2019) 32 LJIL 235.

${ }^{30}$ L. Nuzzo, 'The Birth of an Imperial Location: Comparative Perspectives on Western Colonialism in China', (2018) 31 LJIL 569.

${ }^{31}$ R. Giladi, 'The Phoenix of Colonial War: Race, the Laws of War, and the "Horror on the Rhine"', (2017) 30 LJIL 847.
} 


\section{The dual face of international law}

The current international architecture is marked by a paradox. It has been built on the basis of the power relations and social structures of the past. It is at the same time discredited by it. ${ }^{32}$ As Anthony Anghie, ${ }^{33}$ B. S. Chimni ${ }^{34}$ or Sundhya Pahuja, ${ }^{35}$ and most recently, the UN Special Rapporteur on contemporary forms of racism, racial discrimination, xenophobia and related intolerance, Tendayi Achiume, have emphasized, international law has 'played a central role in consolidating and furthering global structures of racial domination and discrimination'. ${ }^{36}$ Colonialism marked an objectionable structure of governance and political relation that was justified through questionable moral claims (e.g., the 'three Cs' of colonialism: Civilization, Christianity, and Commerce ${ }^{37}$ ) and legal justifications.

Colonial powers gained control through a combination of coercion and partly 'voluntary' and partly 'contrived' consent. ${ }^{38}$ Colonial structures involved domination, exploitation, alienation, and identity-taking. They changed the way in which groups and indigenous populations understood and organized their individual and collective lives. ${ }^{39}$ Colonial law served as an instrument of discipline, coercion (e.g., French code de l'indigénant) or social transformation, including the transformation of local customary law, but it also established limits to colonial power and opportunities for resistance to its control. Race and ethnicity formed the basis of indirect rule. Standards of civilization were modelled after structures of government, law and administration of colonial powers. Social hierarchies and institutional structures denied 'equal and reciprocal terms of cooperation'. ${ }^{40}$ Colonialism has thus been rightly qualified as a form of 'structural historical injustice' by Catherine $\mathrm{Lu} .{ }^{41}$ It involved not only wrongdoing by specific individuals or states, but had a strong international and transnational dimension. ${ }^{42}$ It relied on 'social structural processes that enabled and even encouraged individual or state wrongdoing, and produced and reproduced unjust outcomes'. ${ }^{43}$ Its detrimental consequences remain visible until the present.

Many newly independent states struggled to build independent economies during and after decolonization and remained subject to other, less direct forms of outside control that go beyond their choice, such as colonial debt or currency dependency, external corporate control or exploitation of natural resources. A large number of contemporary conflicts ${ }^{44}$ or migration patterns ${ }^{45}$ have their origins in physical, cultural, and psychological damage caused by decades or centuries of colonial rule.

\footnotetext{
${ }^{32}$ J. Zimmerer, Von Windhuk nach Auschwitz? Beiträge zum Verhältnis von Kolonialismus und Holocaust (2011), 32.

${ }^{33}$ A. Anghie, Imperialism, Sovereignty and the Making of International Law (2012); A. Anghie, 'Towards a Postcolonial International Law', in P. Singh and B. Mayer (eds.), Critical International Law: Postrealism, Postcolonialism and Transnationalism (2014), 123.

${ }^{34}$ B. S. Chimni, 'The Past, Present and Future of International Law: A Critical Third World Approach', (2007) 27 Melbourne Journal of International Law 499.

${ }^{35}$ S. Pahuja, Decolonizing International Law (2011).

${ }^{36}$ Report of the Special Rapporteur on contemporary forms of racism, racial discrimination, xenophobia and racial intolerance, UN Doc. A/74/321 (2019), para. 18.

${ }^{37}$ The three Cs are reflected in Rudyard Kipling's poem 'White Man's Burden' (1899).

${ }^{38}$ See A. Loomba, Colonialism-Postcolonialism (1998), 31.

${ }^{39} \mathrm{R}$. Bhargava, 'How Should We Respond to the Cultural Injustice of Colonialism?', in J. Miller and R. Kumar (eds.), Reparations: Interdisciplinary Inquiries (2007), 215, at 217.

${ }^{40}$ L. Ypi, 'What's Wrong with Colonialism', (2013) 41 Philosophy \& Public Affairs 158.

${ }^{41}$ C. Lu, 'Colonialism as Structural Injustice: Historical Responsibility and Contemporary Redress', (2011) 19 Journal of Political Philosophy 261. See also D. Butt, 'Repairing Historical Wrongs and the End of Empire', (2012) 21 Social \& Legal Studies 227; K. Tan, 'Colonialism, Reparations and Global Justice', in J. Miller and R. Kumar (eds.), Reparations: Interdisciplinary Inquiries (2007), 280.

${ }^{42}$ The colonial experience and the process of decolonization have differed across former colonies. However, colonialism cannot be understood only through national experiences.

${ }^{43}$ See Lu, supra note 41 , at 262.

${ }^{44}$ On Rwanda see M. Mamdani, When Victims Become Killers: Colonialism, Nativism, and the Genocide in Rwanda (2001).

${ }^{45}$ E. Tendayi Achiume, 'Migration as Decolonization', (2019) 91 Stanford Law Review 1509.
} 
International law in the wider sense, including international political and legal institutions and structures, have played a conflicting role. Law is both a culprit and a potential remedy. It makes colonialism 'speakable and unspeakable' at the same time ${ }^{46}$ It has been used to legitimize empire and colonial exploitation. Throughout colonial history, natural law and ethnic and racial distinctions were used to legitimize colonialism. Native legal claims and local contestations and forms of resistance were often suppressed through domination and dispossession. ${ }^{47}$ In the nineteenth century, theories of socio-cultural progress were used as pretexts to justify colonial imperialism ('Scramble for Africa') and commercial expansion as civilization or protection (e.g., Berlin Conference). ${ }^{48}$ Divisions endured under the Mandates System of the League of Nations and beyond. ${ }^{49}$ International law upheld racial hierarchies and social divisions. ${ }^{50}$ Equality remained a fiction. Contemporary norms or silences render colonial violence invisible. Concepts such as intertemporal law, lack of legal personality or statutes of limitations are used to bar claims for reparatory justice. International criminal justice promotes resistance towards oppression, but it approaches injustice predominantly through victim/perpetrator divides that reduce complexity.

At the same time, however, international law also opens pathways towards transformation. ${ }^{51}$ It cannot 'change the past', but it is a means to transform the way in which agents relate to it. It may counter past silences and recognize historical injustices and biases (e.g., oppressive and racialized structures) and change contemporary discourses or domestic practices through the expressive function of law. ${ }^{52}$ Adjudication is not necessarily only a reconstruction of the past or a means to preserve or entrench traditional understandings. It may entail a transformative process which recreates historical objects, links or subjectivities. ${ }^{53}$ Quasi-judicial bodies, such as commissions of inquiry or truth and reconciliation mechanisms, can help challenge traditional narratives, offer alternative legal qualifications of past conduct or identify ways to overcome biases.

In light of the divergent interests of states and the reluctance of former colonial powers to engage with reparations claims, it remains difficult to reach a binding legal agreement. However, some normative change occurs incrementally, through less formal processes, such as practices in the field of human rights (e.g., indigenous rights), cultural heritage law, transitional justice (access to justice) or soft law instruments (e.g., UN Principles Basic Principles and Guidelines on the Right to a Remedy and Reparation). Notions, such as race or civilization have become subject to critical scrutiny, both in policy and law. ${ }^{54}$ UNESCO has emphasized since the 1950s that 'race' is 'not so much a biological phenomenon' but rather a 'social myth'. ${ }^{55}$ The European Race Directive distanced itself expressly from theories 'which attempt to determine

\footnotetext{
${ }^{46}$ See S. Edelbi, 'Making Race Speakable in International Criminal Law', (2020) 16 TWAILR: Reflections, at 8.

${ }^{47}$ S. Belmessous (ed.), Native Claims: Indigenous Law against Empire, 1500-1920 (2011).

${ }^{48}$ See, e.g., J. Westlake, Chapters on the Principles of International Law (1894), 141; Vrdoljak, supra note 2, at 47-51.

${ }^{49}$ See, e.g., A. Anghie, 'Finding the Peripheries: Sovereignty and Colonialism in Nineteenth-century International Law', (1999) 40 Harvard International Law Journal 1. On UN administration see C. Stahn, Law and Practice of International Territorial Administration (2008); E. De Brabandere, Post-conflict Administrations in International Law (2009); R. Wilde, International Territorial Administration: How Trusteeship and the Civilizing Mission Never Went Away (2008).

${ }^{50}$ See M. Koskenniemi, 'Race, Hierarchy and International Law: Lorimer's Legal Science', (2016) 27 EJIL 415.

${ }^{51}$ On change through law see W. Veraart, 'Uitzondering of precedent? De historische dubbelzinnigheid van de Rawagedeuitspraak', (2012) 61 Ars Aequi 251.

${ }^{52}$ On expressivism as method see C. Stahn, Justice as Message (2020).

${ }^{53}$ On the re-theorization of the state see R. Parfitt, The Process of International Legal Reproduction (2019).

${ }^{54}$ See UNESCO, Declaration on Race and Racial Prejudice, adopted by the General Conference at its $20^{\text {th }}$ session, 27 November 1978, Art. 2 (Any theory which 'bases value judgements on racial differentiation, has no scientific foundation and is contrary to the moral and ethical principles of human'). See M. Mutua, 'Critical Race Theory and International Law: The View of an Insider-Outsider', (2000) 45 Villanova Law Review 841.

${ }^{55}$ UNESCO, Statement on Race, Paris, July 1950, in UNESCO, 'Four Statements on the Race Question' (1969), 33. On race in international criminal justice see C. Lingaas, The Concept of Race in International Criminal Law (2019).
} 
the existence of separate races' in its definition of 'racial origin' ${ }^{56}$ Colonial remnants, such as the discrimination between civilized and uncivilized nations (e.g., Article 38 of the ICJ Statute) have been silently abandoned in legal practice. ${ }^{57}$ Legal approaches towards time, agency, and cultural objects are becoming open to alternative readings through litigation, practice, and scholarship. Solutions for colonial injustice must be sought, both within and outside the law.

\section{False binaries and objections to redress}

Colonial injustice requires a wide range of forms of redress, including moral, political, legal or cultural forms of redress. Structurally, it is more difficult to address than other forms of historical injustice. ${ }^{58}$ It covers a large historical time span, ranging roughly from the early sixteenth century to the latter half of the twentieth century. Not every form of injustice relates to colonial violence. Colonial history includes very different periods of colonization and forms of control or domination (e.g., land-taking, political domination, cultural imposition or economic exploitation). ${ }^{59}$ They involve different types of injustice, ${ }^{60}$ such as deprivation of rights or entitlements, unjust exclusions, forms of unjust enrichment (e.g., episodes of exploitation), or rule-based systemic or structural wrongs. ${ }^{61}$ They require different forms of transformative justice (e.g., corrective, restorative, distributive or reconciliatory justice).

The passage of time makes it difficult to identify victims and perpetrators. The strength of claims may fade with the supersession of people and their rights and obligations over time. Harm and violence are not only state-driven. Non-state actors, such as companies (e.g., the Dutch East India Company) or missionaries, have played an ambivalent role in colonial injustice. Some of them were, directly or at least indirectly, agents of colonialism. ${ }^{62}$ In many cases, the nexus between original wrongdoing and present-day reality is transformed or broken through intervening factors. Corrective justice is thus often difficult in legal terms. However, these obstacles do not preclude redress for colonial injustice. Many contemporary objections to reparatory approaches are based on shaky premises or distinctions (e.g., moral vs. legal responsibility, contemporary vs. remote historical injustice, impossibility of relief, responsibility of past vs. present generations).

Many states or actors recognize moral responsibility or political forms of redress as part of a reparative approach towards wrongdoing (apology, forgiveness, contrition, atonement, and reconciliation), but shy away from approaches which would imply any legal recognition of wrong, in

\footnotetext{
${ }^{56}$ See EU Council Directive 2000/43/EC of 29 June 2000, at preamble, para. 6.

${ }^{57}$ See A. Pellet, 'Article 38', in A. Zimmermann and C. J. Tams (eds.), Statute of the International Court of Justice: A Commentary (2019), at 836. See also Judge Ammoun's Separate Opinion in North Sea Continental Shelf, Judgment of 20 February 1969, [1969] ICJ Rep. 1969, 3, at 100 and 133 ('the term "civilized nations" is incompatible with the relevant provisions of the United Nations Charter'). On the use of 'civilization' as argumentative pattern see N. Tzouvala, Capitalism as Civilisation (2020). On a transcivilizational account see O. Yasuaki, International Law in a Transcivilizational World (2017).

${ }^{58}$ See generally J. Thompson, Taking Responsibility for the Past: Reparation and Historical Justice (2002). On obstacles see J. Waldron, 'Superseding Historical Injustices', (2014) 103 Ethics 4.

${ }^{59}$ M. Craven, 'Colonialism and Domination', in B. Fassbender and A. Peters (eds.), Oxford Handbook on History of International Law (2012), 862.

${ }^{60}$ David Miller has suggested a correspondence-based theory of responsibility, in order to recognize the complexity of historical injustice. See D. Miller, National Responsibility and Global Justice (2007), 138.

${ }^{61}$ For a typology see J. von Platz and D. A. Reidy, 'The Structural Diversity of Historical Injustices', (2006) 37 Journal of Social Philosophy 360.

${ }^{62} \mathrm{O}$. Kalu, The History of Christianity in West Africa (1980), 183; A. Johnston, Missionary Writing and Empire, 1800-1860 (2009), 13-37; C. River Editors, The Dutch East India Company and British East India Company: The History and Legacy of the World's Most Famous Colonial Trade Companies (2016). See also G. Baars, The Corporation, Law and Capitalism (2019).
} 
order to avoid precedents. ${ }^{63}$ Acts of repair are presented as an act of solidarity, development or care. For instance, the use of development aid to make up for colonial harm marginalizes wrongdoing. The practice of offering cultural colonial objects on loan to societies of origin portrays temporary return as an act of gratitude, rather than as something that is owed. This logic has self-serving and patronizing features. It reverses roles: Former colonial powers appear as generous benefactors, while former colonized societies are presented as objects of charity.

The exclusive focus on moral responsibility implies that law has nothing to say about colonial injustice and its continuing legacies. The turn to morality overlooks the fact that certain types of colonial injustice were already prohibited according to the standards at the time, such as laws and customs of warfare, principles of humanity or protective duties regarding administered populations under the Final Act of the 1885 Berlin Conference ${ }^{64}$ or protectorate agreements. It also poses a fundamental justice dilemma. Colonialism was legally constructed. Colonial injustices cannot necessarily be resolved by relying on the very laws that caused them. Law was implicated in creating structural conditions of injustice, but it is not only a tool of domination and suppression. It should be revisited in order to have a stake in undoing them. It is thus rightly emphasized that post-colonial engagement with colonial injustices requires a decolonization of international law itself. ${ }^{65}$

A second false binary is the distinction between different types of historical injustice based on the physical existence of offenders or survivors. Contemporary forms of historical injustice, such as the holocaust, are deemed to be open to legal redress for individuals because some of the perpetrators or (direct and indirect) victims are still alive, ${ }^{66}$ while other types of historical injustice are excluded because perpetrators and (direct and indirect) victims have deceased. ${ }^{67}$ This agentrelated understanding neglects the structural nature of colonial injustice. It restricts redress to inter-personal relations and liability structures. It disregards the fact that colonial injustice results often not so much from the injustice done between particular persons, but rather from the structures of abuse or the institutional systems put in place at the time.$^{68}$ It is necessary to differentiate assessment of persons (e.g., individuals, groups) and assessment of actions. ${ }^{69}$ As Wouter Veraart has aptly noted, ' $[u]$ ndoing cases of colonial injustice means addressing a past based on a legalized structure of racial inequalities and deeply entrenched patterns of deliberate and ruthless exploitation of human subjects and destruction of their cultural and ecological environments'. ${ }^{70}$

This is inter alia recognized in the context of transatlantic slavery. For example, Max Du Plessis has argued that reparations might be useful to address 'the legacy of enslavement, rather than to try and redress the historical injustice itself. ${ }^{71}$

A third false objection is the impossibility of relief (e.g., indeterminacy thesis). ${ }^{72}$ Reparation or damages would be impossible to quantify or explode the limits of the law, since they involve

\footnotetext{
${ }^{63}$ For instance, Australia apologized to the 'Stolen Generations' in 2008, but refused to accept legal responsibility. See J. Thompson, 'Collective Responsibility for Historic Injustices', (2006) 30 Midwest Studies in Philosophy 154, at 160.

${ }^{64}$ See General Act of the Berlin Conference on West Africa, 26 February 1885, Art. 6.

${ }^{65}$ See also Report of the Special Rapporteur, supra note 36, para. 58; Anghie, 'Towards a Postcolonial International Law', supra note 33.

${ }^{66}$ For instance, Dinah Shelton has identified several factors which influence the award of reparations: They include (i) whether the perpetrator is identifiable and living, and (ii) whether victims, or their immediate descendants, are identifiable and living. See D. Shelton, Remedies in International Human Rights Law (2015), 277.

${ }^{67}$ De Baets, supra note 11 , at 132.

${ }^{68}$ C. Moon, “Who'll Pay Reparations on My Soul?" Compensation, Social Control and Social Suffering', (2012) 21 Social and Legal Studies 187, at 194.

${ }^{69}$ See Butt, supra note 25.

${ }^{70} \mathrm{~W}$. Veraart, 'Beyond Property: A Reflection on the Value of Restitution of Looted Cultural Objects', 2020, SSRN Electronic Journal, available at papers.ssrn.com/sol3/papers.cfm?abstract_id=3524852.

${ }^{71}$ M. du Plessis, 'Historical Injustice and International Law: An Exploratory Discussion of Reparation for Slavery', (2003) 25(3) Human Rights Quarterly 624, at 651.

${ }^{72}$ Waldron, supra note 58.
} 
injuries or suffering over centuries. This argument neglects the reality of reparative processes. In cases of historical injustice, justice is even more than in other contexts an approximation. Reparative practices move away from restitutio in integrum towards lump sum agreements, collective forms of reparations or measures to address the structural causes of violence or victimization. This is inter alia reflected in post-Second World War peace agreements or the commitment to a 'just and fair' solution in relation to restitution of Nazi-looted art in the Washington Conference. ${ }^{73}$ In cases of colonial injustice, reparatory practices may be used to address ongoing causes and consequences, rather than symptoms. Developments in transitional justice, which are grounded in international legal norms (e.g., access to justice, right to truth) illustrate that reparatory justice can have a truth-telling function, clarify the past, express empathy or a 'society's commitment not to forget or deny that a particular injustice took place', and to respect and help sustain a dignified sense of identity in memory for the people affected. ${ }^{74}$ Reparation for colonial injustice is both an offer 'to repair the relation' and a means to satisfy a 'demand for truth'. ${ }^{75}$

A fourth critique relates to the intergenerational dimensions of redress. ${ }^{76}$ It would be unfair to burden current generations with the duty to repair the wrong of past generations, in particular to provide compensation: present generations should not be required to atone for or repair 'the sins of earlier ones'. ${ }^{77}$ This argument may apply in relation to the responsibility of individuals, but it does not apply to the same extent to responsibilities of legal persons, such as states and corporations which continue to exist. ${ }^{78}$ Contemporary structures are able to take into account intergenerational considerations. It is wrong to conflate redress with compensation, as suggested in popular discourse. As Ruti Teitel has noted, with the passage of time, 'reparatory projects move farther from the traditional model of corrective justice ${ }^{\text {,79 }}$ and towards transformative processes. ${ }^{80}$ Addressing distributive inequalities and the structures that colonial injustice created becomes more central. Contemporary responsibility may thus relate not so much to an undoing of the past, but to recognition of wrong, ${ }^{81}$ and the duty to put an end to the reproduction of injustices.

\section{Relational justice theories}

Relational theories offer more nuanced models to address dilemmas of colonial injustice. They connect justice to consciousness about the continuing effects of colonial injustice in the present and the transformation of contemporary engagement with history and the past in social relations. ${ }^{82}$ Transformation is necessary not only because of the need to remedy wrong, but to create structural changes that prevent the reproduction of inequalities or harms.

Relational theories come in different variations. For example, Iris Young has developed a social connection model of responsibility. ${ }^{83}$ Her approach places the emphasis on social responsibility to others, rather than liability based on agency, guilt or fault for a harm. According to her, the aim should not be solely to repair relations between an offender and a victim, but rather to address the underlying structures of injustice and to renew social relations. This theory is able to

\footnotetext{
${ }^{73}$ Washington Conference Principles on Nazi-Confiscated Art, 3 December 1998, Principles 8 and 9.

${ }^{74}$ Waldron, supra note 58 , at 6.

${ }^{75}$ Sarr and Savoy, supra note 20 , at 40.

${ }^{76}$ See generally J. Thompson, Intergenerational Justice: Rights and Responsibilities in an Intergenerational Polity (2013).

${ }^{77}$ C. Kukathas, 'Who? Whom? Reparations and the Problem of Agency', (2006) 37 Journal of Social Philosophy 330, at 331.

${ }^{78}$ See L. Moffett and K. Schwartz, 'Reparations for the transatlantic slave trade and historical enslavement: Linking past atrocities with contemporary victim populations', (2018) 36 Netherlands Quarterly of Human Rights 247, at 262.

${ }^{79}$ R. Teitel, Transitional Justice (2002), 141.

${ }^{80} \mathrm{P}$. Gready and S. Robins, 'From Transitional to Transformative Justice: A New Agenda for Practice', (2014) 8 International Journal of Transitional Justice 339.

${ }^{81}$ De Baets, supra note 11 , at 149.

${ }^{82}$ As Paul Ricoeur has noted, peoples, groups and individuals define their identity not only through status and cultural bonds, but also through history and memory. See P. Ricoeur, La mémoire, l'histoire et l'oubli (2000).

${ }^{83}$ I. Young, 'Responsibility and Global Justice: A Social Connection Model', (2006) 23 Social Philosophy and Policy 102.
} 
accommodate the collective and intergenerational dimensions of colonial injustice. Contemporary agents are not per se blamed for all the wrong in the past (e.g., guilty of wrong), but rather held responsible for remedying present injustices that are enduring. ${ }^{84}$ This model opens doors for forms of responsibility that are not grounded in agency-based liability (e.g., responsibility without culpability) and oriented towards future-oriented redress. It offers a constructive way to go beyond the narrow confines of individual responsibility which may reduce colonial injustice easily to personal wrongdoing, but it also has weaknesses from a justice perspective since it may marginalize legal responsibility for past wrongs or leave accountability blind spots through its focus on ongoing violations. ${ }^{85}$ The longer the harm dates back, the more tempting it becomes to base responsibility on social connection arguments, such as unjust enrichment.

Other theorists rely on discursive or restorative features of justice processes and procedures in order to address the dynamics of colonial injustice. For instance, Janna Thompson has supported a reconciliatory approach towards historical injustice, ${ }^{86}$ which involves shared forms of responsibility 'to bring about a more just social order' ${ }^{87}$ Reparatory justice should be geared towards co-operation and establishment of trust. One critique of this approach is that it fails to provide a basis for reparative claims in cases where a harmonious relationship now exists between the nations or peoples concerned'. ${ }^{8}$

Others again stress the participatory dimensions of justice and argue that colonial injustice should be addressed in dialogical terms, ${ }^{89}$ namely through open and transparent structures of discourse that allow for contestation, debate and diverse perspectives, including non-Western views. They acknowledge that social interaction may not necessarily bring closure about the past, but provide a voice to unheard communities, transform the way in which the past is narrated, ${ }^{90}$ or promote recognition, empowerment or mutual engagement through a process in which each side has to give way in an effort to reach 'fair and just solutions' ${ }^{91}$

Felwine Sarr and Bénédicte Savoy have developed a transformative relational justice model in relation to cultural colonial objects. These objects have often 'become diasporas' through colonialism. Sarr and Savoy argue that these objects are the very 'mediators of a relation that needs to be reinvented'. ${ }^{92}$ Acts of restitution are thus not only an attempt to address property relations (e.g., return to the 'rightful property owner') or a gesture recognizing wrongdoing, but rather a process of 're-activating a concealed memory' and restoring the 'signifying, integrative, dynamic, and mediating functions' of cultural heritage within contemporary societies. ${ }^{93}$

These relational theories offer an opportunity to re-think legal engagement with colonial injustice. Legitimate claims for reparatory justice may be grounded in two elements, a wrong of the past and the present connection to structural injustice, i.e., enduring norms, institutions, discourses, material conditions, and social hierarchies. The relational approach implies a responsibility to be conscious of relationships to spaces, persons or in the reproduction of wrong. This involves backwards-looking elements, such as a duty to affirm, recognize or remember past wrongs (e.g., through historical inquiry, truth-finding, memorialization), and transformation of the status

\footnotetext{
${ }^{84}$ See also C. Lu, Justice and Reconciliation in World Politics (2017), 161. On the concept of enduring justice see J. Spinner-Halev, Enduring Justice (2012).

${ }^{85}$ On responsibility for crimes as composite acts see ILC Articles on State Responsibility, Art. 15.

${ }^{86}$ Thompson, supra note 58.

${ }^{87}$ J. Thompson, 'Collective Responsibility for Historical Injustices', (2006) 30 Midwest Studies in Philosophy 154, at 167.

${ }^{88}$ See K. Dunn, 'A Sorry Challenge’, (2003) Australian Book Review 59.

${ }^{89}$ A. Bottoms and J. Tankebe, 'Beyond Procedural Justice: A Dialogic Approach to Legitimacy in Criminal Justice', (2013) 102 Journal of Criminal Law and Criminology 119.

${ }^{90}$ See I. Young, Responsibility for Justice (2011), 182.

${ }^{91}$ A. van Mourik, 'How to Acknowledge Colonial Injustice?', Interview with Nicole Immler 26 February 2019, available at www.ind45-50.org/en/how-acknowledge-colonial-injustice-interview-nicole-immler.

${ }^{92}$ Sarr and Savoy, supra note 20 , at 39.

${ }^{93}$ Ibid.
} 
$q u o$, i.e., remedying the continued experience of structural injustice through proper processes ${ }^{94}$ and prevention of perpetuation.

The application of relational approaches entails both, legal and extra-legal dimensions. It requires norms and institutions to recognize wrong, flexible mechanisms of inquiry and redress, as well as societal engagement to change narratives and discourses about the colonial past (e.g., presentation of alternative histories, contextualization of colonial acts or objects).

\section{Towards a 'post-colonial international law'}

Law plays an ambivalent role in redress. It continues to face skepticism, due to its historical biases, its ability to entrench injustices of the past, its selectivity and limited access, or its perception as a form of domination or power, but it is at the same time a potential instrument to mitigate colonial injustice. This is recognized in theories of 'critical legalism'95 and partly reflected in contemporary litigation and practice. As Judge McCombe noted in the Mau Mau case, ' $\mathrm{t}$ ] $\mathrm{he}$ time must come when standing by and doing nothing, by those with authority and ability to stop the abuse, becomes a positive policy to continue it'. ${ }^{96}$

Redress may not only be grounded outside, but also within the law. This requires transformation. Both, non- or quasi-judicial procedures (e.g., inquiry, investigation, search for truth, and reconciliation), as well as classical legal procedures (e.g., reparation, restitution) require guidance on the proper classification of past conduct, in order to make reliable findings or provide meaningful recognition of wrong to victims, survivors or descendants. International law remains imperfect in this regard. For many violations, that qualify as international crimes today, there is not necessarily a corresponding legal label according to the standards of the time. Colonialism as such has not been recognized as a crime. ${ }^{97}$ The historically 'correct' application of the law may be a perpetuation of past injustice.

Scholars like Mari Matsuda have shown that traditional concepts, such as wrong, causation or remedy require a differentiated understanding in relation to types of historical injustice which continue to produce stigma and economic harm. ${ }^{98}$ However, many of the limits that law imposes in its present form are not insurmountable, but connected to choices. For instance, theories of causation involve value judgment. States can abstain from invoking statutes of limitations in proceedings. Concepts of timeliness and time may be adjusted in the context of repair of systemic historical injustice since the very structure and type of injury may have prevented earlier claims.

Court litigation is only an option of last resort and not always well-suited to remedy harm, but it may in some cases have a useful role in highlighting gaps or deficits of domestic systems or mobilizing social imagination. ${ }^{99}$ For instance, in a case concerning French responsibility for colonial slave trade and slavery in Martinique, brought by two associations (International Movement for Reparations Martinique, Word Council of the Pan-African Diaspora) under the French Taubira Law, a French Court dissociated the issues of responsibility and liability. ${ }^{100}$ It rejected

\footnotetext{
${ }^{94}$ S. Amighetti and A. Nuti, 'David Miller's theory of redress and the complexity of colonial injustice', (2015) 8 Ethics \& Global Politics 1, at 9.

${ }^{95}$ M. J. Matsuda, 'Looking to the Bottom: Critical Legal Studies and Reparations', (1987) 22 Harvard Civil Rights-Civil Liberties Law Review 323.

${ }^{96}$ Mutua v. Foreign \& Commonwealth Office, [2011] EWHC 1913 (QB), High Court of Justice, 21 July 2011, para. 144.

${ }^{97}$ In 2019, the National Inquiry into Missing and Murdered Indigenous Women and Girls in Canada recognized the destruction of indigenous peoples as 'colonial genocide'. See National Inquiry into Missing and Murdered Indigenous Women and Girls, 'Supplementary Report, A Legal Analysis of Genocide' (2019), at 9.

${ }^{98}$ Matsuda, supra note 95 , at 398.

${ }^{99} \mathrm{M}$. Bessone, 'The Colonial Slave Trade, Slavery and Structural Racial Injustice in France: Using Iris Marion Young's Social Connection Model of Responsibility', (2019) 20 Critical Horizons 161. See also H. Duffy, Strategic Human Rights Litigation: Understanding and Maximising Impact (2018); ECCHR, 'Colonial Repercussions: Namibia' (2019), available at www.ecchr.eu/ fileadmin/Publikationen/ECCHR_NAMIBIA_DS.pdf.

${ }^{100}$ Tribunal de Grande Instance de Fort de France, Judgment, No R.G. 05/1995, at 25.
} 
a legal duty to repair, but confirmed that the state has a shared responsibility for slave trade and slavery and a duty to guarantee lasting memory (duty of memory). Court cases can thus have an important demonstrative or expressive function in relation to colonial injustice, even if remedies against the state or specific individuals remain limited. They may contribute to the emergence of 'multidirectional memories', ${ }^{101}$ bring out unexpected connections between different types of historical wrong or create novel relational spaces to contemplate justice. ${ }^{102}$

In contemporary practice, modest changes in approach can be witnessed in relation to three themes: the interplay between justice and time, the conceptualization of agency, and the relationship towards cultural colonial objects.

Dilemmas of perpetuating colonial injustice through reliance on laws of the past may be mitigated in three ways: contextual interpretation of past norms, recourse to evolutive interpretation ${ }^{103}$ or the recognition of exceptions to the inter-temporal rule. ${ }^{104}$ For instance, it may be appropriate to recognize certain limits to the application of the intertemporal rule (e.g., jus cogens norms), as suggested by some ICJ judges in the case of Land and Maritime Boundary between Cameroon and Nigeria, ${ }^{105}$ or to extend the spirit of the Radbruch formula to colonial injustice. ${ }^{106}$

The Dutch jurisprudence on reparation in the Rawagede, South-Sulawesi and East Java cases has challenged the traditional view that claims regarding historical injustice are per se barred by evidentiary obstacles. ${ }^{107}$ It concerned only specific episodes of violence in the path towards decolonization, but confirmed an important principle, namely that domestic legislators may be barred by virtue of international legal principles and considerations of fairness and good faith, to silence all consequences of the colonial past through statute of limitations. The limits of statutory limitations regarding historical injustice were confirmed by two historic rulings of the Hague Court of Appeal in 2019. ${ }^{108}$ They clarified essential elements of the 'reasonableness and fairness' test, namely the 'exceptional nature of the unlawful conduct' ${ }^{109}$ (or better: the serious nature of the crimes), state knowledge and failure to act (e.g., violation of due diligence/duty of care), ${ }^{110}$ and unfairness of a strict application of the period of limitation towards the claimant (e.g., de facto impossibility for the claimant to seek access to justice for a long period of time, existence of state immunity before foreign courts). ${ }^{11}$ The rulings compelled the Dutch government to assume responsibility and express apologies, as a follow-up of legal proceedings. ${ }^{112}$

Approaches towards legal subjectivity are evolving. Colonial practices marginalized the identity of colonial entities. They involved a dual form domination: they treated people as objects of colonial will, i.e., as entities lacking equal status, and then re-made them as subjects. However,

\footnotetext{
${ }^{101}$ M. Rothberg, Multidirectional Memory: Remembering the Holocaust in the Age of Decolonization (2009).

${ }^{102} \mathrm{~N}$. Immler, 'Human Rights as a Secular Social Imaginary in the Field of Transitional Justice', in H. Alma and G. Vanheeswijck (eds.), Social Imaginaries in a Globalizing World (2018), 193, at 212.

${ }^{103}$ M. Goldmann and B. von Loebenstein, 'Alles nur geklaut? Zur Rolle juristischer Provenienzforschung bei der Restitution kolonialer Kulturgüter', (2020) MPIL Research Paper Series No. 2020-19, at 6.

${ }^{104}$ On the role of interpretation in framing international law see I. Venzke, How Interpretation Makes International Law: On Semantic Change and Normative Twists (2012).

${ }^{105}$ Land and Maritime Boundary between Cameroon and Nigeria (Cameroon v. Nigeria: Equatorial Guinea intervening), Judgment of 10 October 2002, [2002] ICJ Rep. 2002, 303, Separate Opinion of Judge Ranjeva, para. 3.

${ }^{106} \mathrm{~A}$. Buser, 'Colonial Injustices and the Law of State Responsibility', (2017) 77 ZaöRV 409, at 432-3.

${ }^{107}$ L. van den Herik, 'Reparation for Decolonisation Violence: A Short Overview of Recent Dutch Litigation', (2018) 78 ZaöRV 629, at 632-3.

${ }^{108}$ Children of executed men in South-Sulawesi v. The Netherlands, Case no. 200.243.525/01, 1 October 2019, The Hague Court of Appeal; Heirs Java torture victim v. The Netherlands, Case no. 200.247.634/01, 1 October 2019, The Hague Court of Appeal.

${ }^{109}$ Children of executed men in South-Sulawesi, ibid., para. 15.2.

${ }^{110}$ Ibid., para. 15.3

${ }^{111}$ Ibid., para. 15.4.

${ }^{112}$ Volder and de Brouwer, supra note 16 , at $62-3$.
} 
the status of international law regarding legal personality of non-state entities in the colonial era is more complex than assumed. Many colonial entities (tribes, chiefdoms, kingdoms etc.) had their own organically grown forms of self-government and social rules organizing society. Some entities exercised forms of sovereignty that do not conform with Eurocentric political systems (e.g., tribal sovereignty). In many settler colonial contexts (e.g., US, Canada, New Zealand, Australia), treaty processes are used as a means to address historical grievances, support mutual recognition or create space for belated nation-building (e.g., Uluru Statement from the Heart). ${ }^{113}$

New historical research in international law suggests that local political entities enjoyed at least relative international legal personality throughout colonial history. As Mamadou Hébié has shown, many agreements concluded in the colonial expansion of Africa created binding legal obligations for both parties and rights opposable to other colonial powers. ${ }^{114}$ This practice indicates that statehood was not necessarily a condition sine qua non for the recognition of legal personality and that local entities were deemed to enjoy treaty-making capacity in certain contexts (e.g., conferral of titles to sovereignty) ${ }^{115}$ In light of this, it does not always make sense to require that the interests of a people are mediated through the state in negotiations or claims. ${ }^{116}$ A legitimate interest of peoples or groups to participate and be heard may flow from other norms, such as self-determination, equality or non-discrimination or cultural rights. ${ }^{117}$ This is inter alia recognized in the UN Declaration on the Rights of Indigenous Peoples. ${ }^{118}$

Perspectives on ownership and return of cultural colonial objects are evolving. Many artefacts are 'witnesses to history' (Walter Benjamin). ${ }^{119}$ They tell a story of the past or represent history and culture of societies. Restitution and reparation are a means to reconstitute dignity, transform relations towards objects and turn societies of origin from history's objects into subjects. ${ }^{120}$ According to a relational view, claims for restitution of objects to societies of origin, or different forms of ownership, may not only be justified by the wrong of the past (e.g., unlawful taking according to the standards of time), but grounded in the inherent link between people and cultural heritage and their ability to develop their own cultural identity. This argument has been made in different variations: the entitlement of a state to have access to the 'keys to its history' (e.g., removal of Parthenon Marbles from Greece during the former Ottoman Empire), ${ }^{121}$ the link between a people's right of self-determination and cultural identity (e.g., return of Venus of Cyrene to Libya), ${ }^{122}$ and human rights-based approaches which seek to protect the dignity

\footnotetext{
${ }^{113}$ See A. Cobb, 'Understanding Tribal Sovereignty: Definitions, Conceptualizations, and Interpretations', (2005) 46 American Studies 115. See also H. Hobbs, 'Treaty making and the UN Declaration on the Rights of Indigenous Peoples: Lessons from Emerging Negotiations in Australia', (2019) 23 International Journal of Human Rights 174.

${ }^{114}$ For example, the Herero entered into protection treaties with Germany in 1885 and 1890.

${ }^{115} \mathrm{M}$. Hébié, 'The Role of the Agreements Concluded With Local Political Entities in the course of French Colonial Expansion in West Africa', (2015) 85 British Yearbook of International Law 21, at 89.

${ }^{116}$ On the Herero negotiation see S. Harring, 'German Reparations to the Herero Nation: An Assertion of Herero Nationhood in the Path of Namibian Development', (2002) 104 West Virginia Law Review 393.

${ }^{117}$ On art restitution see J. von Bernstoff and J. Schuler, 'Wer spricht für die Kolonisierten? Eine völkerrechtliche Analyse der Passivlegitimation in Restitutionsverhandlungen', (2019) 79 ZaöRV 553, at 576-7.

${ }^{118}$ UN Declaration on the Rights of Indigenous Peoples, 13 September 2007, Art. 18.

${ }^{119}$ See also L. V. Prott (ed.), Witnesses to History - Documents and writings on the return of cultural objects (2009).

${ }^{120}$ See Sarr and Savoy, supra note 20 , at 32.

${ }^{121}$ Webb v. Ireland [1988] I.R. 353, at 383, High Court of Justice; Government of Iran v. Barakat Galleries Ltd, [2007] EWCA Civ 1374, 29 March 2007, para. 2. On the Parthenon marbles see generally G. Robertson, Who Owns History? (2020).

${ }^{122}$ The Italian Council of State held that the right to self-determination protects 'the identity as well as the historic and cultural heritage linked to the territory of each state or anyhow belonging to a population subjected to foreign domination'. See Consiglio di Stato, Associazione nazionale Italia Nostra Onlus c. Ministero per i beni e le attività culturali et al., Decision No. 3154/2008, 23 June 2008, para. 4.4, translation by F. Lenzerini, 'Italy', in T. Kono (ed.), The Impact of Uniform Laws on the Protection of Cultural Heritage (2010), 439, at 462.
} 
and property of persons, including the cultural identity of groups and communities (e.g. Benin Bronzes). ${ }^{123}$

The human rights-based reading of cultural heritage is the most innovative approach. It treats objects not merely as cultural property or commodities but also recognizes their human dimension and connection to the identity and development of individuals and communities of origin. It is inter alia reflected in the UNESCO Declaration on the Intentional Destruction of Cultural Heritage, ${ }^{124}$ the ASEAN Declaration on Cultural Heritage ${ }^{125}$ or the Council of Europe's Framework Convention on the Value of Cultural Heritage for Society (Faro Convention). ${ }^{126}$ It enables a 'social connection'-oriented approach towards colonial injustice. Under this approach, the 'disconnection which may occur between cultural heritage and the people concerned' becomes an 'important human rights issue' of its own. ${ }^{127}$ The key question is not so much whether acquisition of ownership or removal of objects was lawful at the time, but rather whether the contemporary lack of connection to objects by certain heritage communities constitutes a social condition which requires redress. ${ }^{128}$

These approaches are the first steps towards an overdue decolonization of international law. International law should not be treated as a 'sacred source of authority', but rather as part of a particular 'historically and geographically situated tradition'. ${ }^{129}$ Contemporary developments, such as the protests of the 'Black Lives Matter' movement, the deconstruction and de-heroization of colonial monuments, the ongoing demand for apology or reparations and challenges to the exclusive guardianship role of international museums ${ }^{130}$ serve as a reminder that many effects of colonial injustice are still felt as ongoing and real by individuals, peoples and communities. ${ }^{131}$ One of the challenges of the next decades is to confront structural injustices more openly and decisively and to develop foundations of a 'post-colonial international law', not only in the field of justice and accountability, but also in many other fields (e.g., migration, international economic law, state succession). ${ }^{132}$ Transitional justice may need to be understood in a new relational way in relation to colonial injustice, namely as a means to transform unjust into just relations.

\footnotetext{
${ }^{123}$ See Campfens, supra note 2 , at 98 et seq.

${ }^{124}$ UNESCO Declaration on the Intentional Destruction of Cultural Heritage (2003), preamble.

${ }^{125}$ ASEAN Declaration on Cultural Heritage (2000), preamble.

${ }^{126}$ Faro Convention, preamble.

${ }^{127}$ Report of the independent expert in the field of cultural rights, Farida Shaheed, UN Doc. A/HRC/17/38 (2011), para. 14.

${ }^{128}$ Campfens, supra note 2, at 106.

${ }^{129}$ See F. Mégret, 'The MMIWG report: A Call for decolonizing international law itself, The Conversation, 9 June 2019, available at theconversation.com/the-mmiwg-report-a-call-for-decolonizing-international-law-itself-118443.

${ }^{130}$ See the 2002 Declaration on the Value and Importance of Universal Museums, signed by 18 large Western museums.

${ }^{131}$ Tourme-Jouannet, supra note 14 , at 197.

${ }^{132} \mathrm{C}$. Lu, 'Responsibility, Structural Injustice, and Structural Transformation', (2018) 11 Ethics \& Global Politics 42, at 52.
} 